\title{
Corporate Governance Mechanisms and Voluntary Disclosure
}

\author{
Erwin Saraswati $^{1, a *}$, Alfizah Azzahra ${ }^{2, b}$, Ananda Sagitaputri ${ }^{1, \mathrm{c}}$ \\ ${ }^{1}$ Department of Accounting, Faculty of Economics and Business, Universitas Brawijaya \\ J1. MT. Haryono No. 165 Malang \\ East Java, Indonesia \\ e-mail: ${ }^{a} *$ Erwin_saraswati@yahoo.com, ${ }^{b}$ alfizahraa@gmail.com, ${ }^{\mathrm{c}}$ ananda.sagitaputri@ outlook.com \\ * Corresponding Author
}

\begin{abstract}
Corporate disclosure and corporate governance are two inseparable instruments of investor protection. This research sought to find evidence on how corporate governance mechanisms affect the extent of voluntary disclosures. Voluntary disclosures were measured using content analysis on published annual reports. The sample of this research consisted of 81 firm-year observations from 27 firms of consumer goods sector listed on Indonesian Stock Exchange from 2016 to 2018. Using multiple regression method, the result has shown that board size and board independence increase voluntary disclosures, indicating that the commissioners have effectively represented the interests of shareholders by monitoring and encouraging the management to increase disclosure. This research provided new evidence that family ownership increases voluntary disclosure, suggesting that family firms are more concerned by the costs of nondisclosure. Meanwhile, institutional ownership does not significantly affect voluntary disclosure.
\end{abstract}

Keywords: Annual Report, Corporate Governance, Voluntary Disclosure

Article History: Received: September, 12020 Revised: September, 102020 Accepted: September, 302020

How to cite: Saraswati, E., Azzahra, A., \& Sagitaputri, A. (2020). Corporate Governance Mechanisms and Voluntary Disclosure. Akrual: Jurnal Akuntansi, 11(2):82-94.

DOI: https://doi.org/10.26740/jaj.v11n2.p82-94

\section{INTRODUCTION}

Corporate disclosure and corporate governance are two inseparable instruments of investor protection (Allegrini \& Greco, 2013). In 2014, Indonesian authorities of capital market have declared a corporate government reformation and published a corporate governance roadmap with a goal of improved investor trust and competitiveness in the ASEAN market. One focus of the reformation is corporate disclosure as the key factor of capital market development.

The practice of corporate disclosure in Indonesia is still in its early stage of development. The assessment of 2015 ASEAN CG Scorecard shows that the level of Indonesian companies' disclosure and transparency is ranked fifth out of six countries, lagging behind Thailand, Singapore, Philippines, and Malaysia. Meanwhile, a 2018 survey conducted by ACGA and CLSA shows that Indonesian transparency score of 63.1 is below the average of 69.7. The survey states that Indonesian companies only disclose mandatory 
information, while the environmental, social, and governance (ESG) disclosure practices are very low.

In the increasingly competitive market, mandatory disclosure alone is not sufficient to fulfill the users' needs of information (Elfeky, 2017). Hence, the demand for voluntary disclosure is increasing, especially for public companies (Akhtaruddin and Haron, 2010; Dicko et al., 2019). For companies, voluntary disclosure introduces extra benefits, including increase in equity value and market liquidity, and reduced cost of capital (Akhtaruddin and Haron, 2010). Disclosure also reduces information asymmetry and mitigates the agency conflict between the managers and the shareholders (Dicko et al., 2019; Indriani, 2013).

Researchers have studied the determinants of voluntary disclosure, and most of them base their research on the agency theory. Agency theory argues that agency conflict will arise from the contractual agreement between the agent and the principal. When shareholders (as principal) delegate the decision making of the company to the management (as agent), the management does not bear the loss of the shareholders, so the management may not act on the best interests of the shareholders (Jensen and Meckling, 1976; Godfrey, 2010). Shareholders depend upon corporate governance and disclosure as means of accountability (Hamdani, 2016; Hadiprajitno, 2014). Corporate disclosure can limit managerial opportunism as well as information asymmetry and agency conflict (Kolsi, 2017; Indriani, 2013).

Voluntary disclosures, as a decision made by the top management, are largely influenced by the board structure as the highest control mechanism in a company (Dicko et al., 2019). However, most studies regarding corporate governance mechanisms and their impacts to voluntary disclosure were conducted in one-tier board systems (Kolsi, 2017; Elfeky, 2017; Samaha and Dahawy, 2011; Donnelly and Mulcahy, 2008; Huafang and Jianguo, 2007). Hence, the results of those research may not be applicable in Indonesia which uses the two-tier board system, where there is separation between board of directors which represents the management and board of commissioners as the oversight board. The research results have not been conclusive. Although most studies agreed that larger boards lead to more extensive disclosure (Poluan and Nugroho, 2015; Allegrini and Greco, 2013; Marfuah and Cahyono, 2011; Akhtaruddin and Haron, 2010), some studies found the relation to be insignificant (Kolsi, 2017; Elfeky, 2017; Rafifah and Ratmono, 2015). Most studies also found that board independence increases voluntary disclosure (Elfeky, 2017; Poluan and Nugroho, 2015; Samaha and Dahawy, 2011; Akhtaruddin and Haron, 2010; Donnelly and Mulcahy, 2008; Huafang and Jianguo, 2007). However, studies conducted in Indonesia have found the relation to be insignificant (Rafifah and Ratmono, 2015; Silaban, 2015; Cahyaningsih and Martina, 2011) indicating that the independent commissioners may not be effective in their monitoring (Cahyaningsih and Martina, 2011).

Ownership structure also determines the extent of voluntary disclosure, although the research results are still mixed. This is because different types of shareholders have 
different preferences in regards to voluntary disclosures (Chen et al., 2006). Huafang and Jianguo (2007) found that blockholding ownership increases voluntary disclosure, which was inconsistent with other findings of the opposite direction (Kolsi, 2017; Elfeky, 2017; Samaha and Dahawy, 2011; Barako et al., 2006). Institutional ownership was found to positively affect voluntary disclosure (Silaban, 2015; Barako et al., 2006), while some other studies including ones conducted in Indonesia found the relationship to be insignificant (Poluan and Nugroho, 2015; Rafifah and Ratmono, 2015; Cahyaningsih and Martina, 2011; Donnelly and Mulcahy, 2008; Eng and Mak, 2003). Family ownership and voluntary disclosure have not been widely studied, but the existing studies found the relationship to be negative (Darmadi and Sodikin, 2013; Chau and Gray, 2010).

This study is intended to provide evidence on how corporate governance mechanisms, i.e. board size, board independence, institutional ownership, and family ownership, affect the extent of voluntary disclosure of Indonesian listed companies. This study will provide contributions to the corporate governance and disclosures literature in two-tier board systems. The results of this study can hopefully contribute in increasing the voluntary disclosures of companies, hence improving the corporate governance practices in Indonesia and supporting the CG reformation. The sample of this research are listed companies in consumer goods subsector for the period of 2016 to 2018. This subsector is chosen because it has greater public visibility, so their disclosures or non-disclosures can directly affect the decision-making of the public (Indriani, 2013).

\section{Hypotheses Development}

The agency theory stipulates that in publicly held companies, agency conflicts and information asymmetry can be alleviated by voluntary disclosures (Dicko et al., 2019; Kolsi, 2017). Voluntary disclosure can be affected by the structure of the board of commissioners, since they hold the highest control mechanism in a management with a duty to oversee the policies and performance of the management (Marfuah \& Cahyono, 2011; Effendi, 2009). The board of commissioners will encourage better transparency and disclosure to maximize firm value (Marfuah \& Cahyono, 2011). A bigger board should be able to do better monitoring, minimize management opportunism and encourage the management to disclose more information (Kolsi, 2017; Poluan \& Nugroho, 2015). Studies have found that bigger boards disclose more in their annual reports (Poluan \& Nugroho, 2015; Allegrini \& Greco, 2013; Marfuah \& Cahyono, 2011; Akhtaruddin \& Haron, 2010). Hence, we hypothesize that:

\section{H1: Board size is positively related to voluntary disclosure}

Based on the agency theory, independent directors and commissioners can ease conflicts among the controlling and minority shareholders (Allegrini, 2013). Since independent commissioners come from unaffiliated parties, they are expected to represent the minority shareholders (KNKG, 2006). They are seen as a check and balance mechanisms to ensure 
that management actions serve the best interests of shareholders and other stakeholders (Haniffa and Cooke, 2005). Highly independent boards are linked to improved monitoring and transparency (Immanuel, 2015; Gantyowati \& Nugraheni, 2014; Samaha \& Dahawy, 2011). Studies show that the more independent commissioners sit on the board, the more extensive the voluntary disclosures (Elfeky, 2017; Poluan \& Nugroho, 2015; Samaha \& Dahawy, 2011; Akhtaruddin \& Haron, 2010; Donnelly \& Mulcahy, 2008; Huafang and Jianguo, 2007). Based on the premises above, we hypothesize that:

\section{H2: Board independence is positively related to voluntary disclosure}

Based on the agency theory, substantial shareholders have greater power and incentives to monitor management since their wealth are tied to the company's financial performance (Jensen and Meckling, 1976). Institutional investors have stronger incentives to monitor voluntary disclosures due to their large ownership stake (Barako et al, 2006). Thus, managers will disclose more information to satisfy investors' needs and maintain investors' confidence (Kolsi, 2017; Barako et al. 2006). Although the available empirical evidence are mixed, some found that institutional ownership increases voluntary disclosures (Silaban, 2015; Barako et al., 2006). Hence, we hypothesize that:

\section{H3: Institutional ownership is positively related to voluntary disclosure}

Although we have discussed how institutional investors prefer more voluntary disclosures, studies have found that not all shareholders are alike (Chen et al., 2008). Family firms are characterized with the founding family's concentrated ownership and involvement in the management as directors (Chau \& Gray, 2010; Chen et al., 2008). Family firms are linked to better monitoring but lower information asymmetry due to the family members being both owners and top management (Chen et al., 2008). Family owners will have direct access to information, thus having less incentives to monitor the public voluntary disclosures (Chau \& Gray, 2010). The relationship between family holdings and voluntary disclosure have not been widely discussed, but the existing studies found a negative relationship (Darmadi \& Sodikin, 2013; Chau \& Gray, 2010). Hence, we hypothesize that:

\section{H4: Family ownership is negatively related to voluntary disclosure}

\section{RESEARCH METHOD}

Population and Sample

The research population are firms listed in the consumer goods sub-sector of Indonesian Stock Exchange from 2016 to 2018. This subsector is chosen because it has greater public visibility, so their disclosures or non-disclosures can directly affect the decision-making of the public (Indriani, 2013). The research uses purposive sampling with several criteria, as shown in table 1. 
Table 1. Sampe Selection Process

\begin{tabular}{llc}
\hline No & \multicolumn{1}{c}{ Criteria } & $\begin{array}{c}\text { No. of } \\
\text { Firms }\end{array}$ \\
\hline 1 & $\begin{array}{l}\text { Firms listed in the consumer goods sub-sector } \\
\text { of Indonesian Stock Exchange from 2016 to }\end{array}$ & 53 \\
& 2018 \\
2 & $\begin{array}{l}\text { Firms not continuously listed from 2016 to } \\
2018 \\
3\end{array}$ & $\begin{array}{l}\text { Firms which have incurred net loss between } \\
2016 \text { to 2018 }\end{array}$ \\
\hline & Final number of sample firms & $(8)$ \\
\hline & Total firm-year observations & 81 \\
\hline
\end{tabular}

The sample selection process resulted in 27 sample firms. The research period is three years from 2016 to 2018 , resulting in 81 firm-year observations.

\section{Data Collection}

This research utilizes secondary data. The voluntary disclosure data are obtained through content analysis of the annual reports. Corporate governance mechanisms data are obtained from annual reports, with the exception for the family ownership data which are gathered from various sources on the internet. The annual reports are collected from Indonesian Stock Exchange official website (www.idx.co.id) and from official corporate website.

\section{Variable Measurement}

The dependent variable is the extent of corporate voluntary disclosure. This variable was measured using content analysis on the companies' annual reports. The indicators used for the content analysis are based on Sari \& Juliarto (2016). Content analysis was conducted by giving the score 1 for each indicator that was disclosed, and 0 for indicators that were not disclosed. The total scores were indexed by dividing them to the maximum score.

$$
\text { DISC }=\frac{\Delta \mathrm{Q}}{\Delta \mathrm{S}}
$$

Where:

$\mathrm{Q}=$ Number of indicators disclosed

$\mathrm{S}=$ Total number of indicators

The independent variables board size (BOARD) was measured by the total number of commissioners in a given observation.

$$
\text { BOARD }=\text { Number of commissioners }
$$


Board independence (INDEP) is measured by the proportion of the independent commissioners to the total number of commissioners. An independent commissioner is defined as a commissioner who does not have any business or familial affiliation with any controlling shareholder, other directors or commissioners, and the company itself (KNKG, 2006).

$$
\text { INDEP }=\frac{\text { Number of independent commissioners }}{\text { Number of commissioners }}
$$

The institutional ownership (INST) variable is measured by the percentage of shares owned by other institutions, such as banks, insurance companies, or pension funds, to the total number of shares outstanding.

$$
\text { INST }=\frac{\text { Number of shares owned by institutional investors }}{\text { Number of shares outstanding }}
$$

Family ownership (FAM) is tracked using steps from Sumarsono (2014). First, we identify the family name by scanning the names of the shareholders, directors, and commissioners and finding surnames which frequently appear. Second, we track the history of ownership in the company prospectus, to identify the controlling family. Third, we search the internet for potential family members' names, knowing that not all family ties are reflected in the surname. Finally, we measure the percentage of shares which is owned by the controlling family.

$$
\mathrm{FAM}=\frac{\text { Number of shares owned by the controlling family }}{\text { Number of shares outstanding }}
$$

The control variables used in the study are firm size (SIZE) and auditor size (AUDIT). Firm size is measured by natural logarithm of total assets. Auditor size is a dummy variable which the score 1 is given to firms audited by members of Big Four firms.

Hence, we built the model as follows.

$$
\text { DISC }=\alpha+\beta 1 \text { BOARD }+\beta 2 \text { INDEP }+\beta 3 \text { INST }+\beta 4 \text { FAM }+\beta 5 \text { SIZE }+\beta 6 \text { AUDIT }+\varepsilon
$$

Where:

$\begin{array}{ll}\text { DISC } & \text { : Extent of voluntary disclosure } \\ \text { BOARD } & \text { : Board size } \\ \text { INDEP } & \text { : Board independence } \\ \text { INST } & : \text { Institutional ownership } \\ \text { FAM } & \text { : Family ownership } \\ \text { SIZE } & \text { : Firm size } \\ \text { AUDIT } & : \text { Auditor size }\end{array}$




\section{RESULTS AND DISCUSSION}

The descriptive statistics of the variables are shown in Table 2. The extent of voluntary disclosure (DISC) data fell between 9 to 72 percent, with an average of 32 percent. This shows that the overall disclosure practice was less extensive. This finding was in line with the assessment of the international surveys such as ASEAN CG Scorecard, CLSA and ACGA, which found that Indonesian companies' disclosures were lacking and below average when compared to their Asian peers.

Table 2. Descriptive Statistics

\begin{tabular}{|c|c|c|c|c|c|}
\hline & $\mathrm{N}$ & Min & Max & Mean & $\begin{array}{l}\text { Std } \\
\text { Dev }\end{array}$ \\
\hline DISC & 81 & 0,09 & 0,72 & 0,32 & 0,12 \\
\hline BOARD & 81 & 2 & 8 & 4,48 & 1,43 \\
\hline INDEP & 81 & 0,20 & 0,80 & 0,38 & 0,16 \\
\hline INST & 81 & 0,23 & 0,86 & 0,43 & 0,12 \\
\hline FAM & 81 & 0,00 & 0,63 & 0,12 & 0,33 \\
\hline SIZE & 81 & 11,98 & 18,39 & 15,02 & 1,56 \\
\hline AUDIT & 81 & 0,00 & 1,00 & 0,57 & 0,50 \\
\hline
\end{tabular}

The board of commissioners' size (BOARD) was ranging from 2 to 8 members, with an average of 4 members. 20 to 80 percent of those members were independent commissioners (INDEP). This shows that each company had at least one independent commissioner, as mandated by the Law no 40 of 2007 on Limited Liability Company. Institutional ownership (INST) was ranging from 23 to 86 percent, with an average of 43 percent. Family ownership (FAM) was ranging from 0 to 63 percent, with an average of 12 percent. 13 out of 27 firms were not owned by families. The statistics also show that 57 percent of companies were audited by the members of Big Four accounting firms.

Table 3. Voluntary Disclosure by Year

\begin{tabular}{cc}
\hline Year & Average Voluntary Disclosure \\
\hline 2016 & $34,70 \%$ \\
2017 & $28,59 \%$ \\
2018 & $34,13 \%$ \\
\hline Source: data Author &
\end{tabular}

Table 3 shows the trend of voluntary disclosure over the research period. From the table we can see that the voluntary disclosure was highest in 2016 with an average of $34,70 \%$. It dropped by 6 percent in 2017 to $28,59 \%$, then climbed back up to $34,13 \%$ in 2018. The variation in the data each year suggests that most companies had different policies and behaviors each year in relation to its voluntary disclosure. 


\section{Hypotheses Testing}

We have conducted several tests to determine the best estimation model among common effect, fixed effect, and random effect models. The Chow test resulted in Prob $>F$ value of 0,6346 , indicating that the common effect model was better than the fixed effect model. The Hausman test resulted in Prob>Chi2 value of 0,2325, indicating that the fixed effect model is better than the random effect model. Lastly, the Lagrange Multiplier test showed a Prob>Chibar2 value of 0,1714 , indicating that the common effect model was better than random effect model. In sum, we have chosen the common effect model as the best fitted estimation model to use in this study.

We have tested the classical assumptions to ensure that the model has met the best linear unbiased estimator (BLUE) conditions. First, we conducted normality testing of Kolmogrov-Smirnov which results in a significance level of $0,637(\alpha>0,05)$. The result indicates that the data was normally distributed. We also have conducted the multicollinearity testing which shows a Variance Inflation Factor (VIF) below 10 on each variable, suggesting that there was no multicollinearity issue. The heteroscedasticity testing shows a scatter plot which follows a random pattern, suggesting a homoscedastic data. Hence, all the classical assumptions of the model were met.The hypotheses were tested using common effect multiple linear regression, and the result is shown in Table 4.

Table 4. Hypotheses Testing

\begin{tabular}{cccc}
\hline Model & B & T & Sig. \\
\hline (Constant) & $-0,945$ & $-1,735$ & 0,096 \\
BOARD & 0,332 & 3,246 & $0,004 * *$ \\
INDEP & 0,385 & 2,869 & $0,009 * *$ \\
INST & $-0,007$ & $-0,526$ & 0,604 \\
FAM & 0,033 & 2,777 & $0,011^{*}$ \\
SIZE & $-0,033$ & $-1,715$ & 0,100 \\
AUDIT & $-0,090$ & $-1,195$ & 0,244 \\
\hline F value & & 3,151 & \\
Significance & 0,021 & \\
Adj R square & 0,308 & \\
*significant at $\alpha=0,05$ & & \\
**significant at $\alpha=0,01$ & & \\
Source: data Author &
\end{tabular}

The multiple regression result shows an $\mathrm{F}$ value of 3,151 with significance level of $0,021(\alpha<0,05)$. The adjusted $\mathrm{R}$ square value was $30,8 \%$. These show that the model could be used to explain the voluntary disclosure phenomena in Indonesia. The regression equation was as follows:

$$
\begin{gathered}
\text { DISC }=-0,945+0,332 \text { BOARD }+0,385 \text { INDEP }-0,007 \text { INST }+0,033 \text { FAM } \\
-0,033 \text { SIZE }-0,009 \text { AUDIT }+\varepsilon
\end{gathered}
$$


The result shows that board size (BOARD) has a significant positive impact to voluntary disclosure with $99 \%$ confidence level. Hence, H1 was accepted. This result is consistent with the previous findings (Poluan \& Nugroho, 2015; Allegrini \& Greco, 2013; Marfuah \& Cahyono, 2011; Akhtaruddin \& Haron, 2010). This result supports the agency theory that information asymmetry can be alleviated by voluntary disclosures (Dicko et al., 2019; Kolsi, 2017), and it is the job of the commissioners to oversee the voluntary disclosures from the management (Marfuah \& Cahyono, 2011; Effendi, 2009). More commissioners lead to better monitoring, hence encouraging the management to disclose more information..

The result also shows that board independence (INDEP) significantly increase voluntary disclosure at $99 \%$ confidence level, accepting H2. This result is consistent with the previous studies (Elfeky, 2017; Poluan \& Nugroho, 2015; Samaha \& Dahawy, 2011; Akhtaruddin \& Haron, 2010; Donnelly \& Mulcahy, 2008; Huafang \& Jianguo, 2007). However, it contrasts with previous Indonesian evidence (Rafifah \& Ratmono, 2015; Silaban, 2015; Cahyaningsih \& Martina, 2011) which found no significant relationship. This current finding suggests that independent commissioners have successfully represented the interests of shareholders and effectively overseen the management. This supports the argument of Darmadi \& Sodikin (2013) that the independence and objectivity of the independent commissioners can mitigate managerial opportunism and conflicts of interest.

Institutional ownership (INST) was not found to significantly affect voluntary disclosure. Hence, H3 which suggested a negative relationship was rejected. This finding is consistent with some previous studies (Poluan \& Nugroho, 2015; Rafifah \& Ratmono, 2015; Cahyaningsih \& Martina, 2011; Donnelly \& Mulcahy, 2008; Eng \& Mak, 2003). It has been argued that institutional investors pay more attention to financial performance than voluntary disclosure (Cahyaningsih \& Martina, 2011; Nuryaman, 2009). Donnelly \& Mulcahy (2008) indicates a possibility that institutional investors have a more effective means of communication with the management, e.g. formal meeting with the directors, hence they do not pay much attention to public disclosure.

Family ownership (FAM) was found to significantly increase voluntary disclosure at 95\% confidence level. Hence, $\mathrm{H} 4$ which suggested a negative relationship was rejected. This finding contrasted Darmadi \& Sodikin (2013) and Chau \& Gray (2010) which found a negative relationship. To explain this positive relationship, we use the cost benefit analysis in corporate disclosures which suggests that management considers the costs and benefits of disclosures in their decision making (von Alberti-Alhtaybat et al., 2012). When families have a large stake in a company, they can reap more benefits of disclosure, while also bearing more costs of non-disclosure (Chen et al., 2008). Chen et al. (2008) explained that concealing bad news may incur significant reputation and litigation costs. Reputation costs come from decline in share prices. Litigation costs come from direct costs, i.e. attorney fees, and indirect costs, i.e. the opportunity costs due to wasted time managing the 
settlement rather than in value-adding activities. When a family-held company does not disclose certain news that result in share price decline, it may hurt the family's overall wealth. Hence, family firms disclose more due to their sensitivity to litigation and reputation issues.

The control variable firm size (SIZE) does not have a significant impact to voluntary disclosure, consistent with several studies (Kolsi; 2017; Fitri, 2016; Indriani, 2013; Samaha \& Dahawy, 2011; Makhija \& Patton, 2004). This indicates that companies need to disclose information to mitigate agency conflicts, regardless of their sizes. The auditor size (AUDIT) also does not significantly affect voluntary disclosure. This suggests that Big Four auditors do not encourage companies to disclose information beyond what is mandatory.

\section{CONCLUSION}

Corporate disclosure and corporate governance are two inseparable instruments of investor protection. This research seeks to provide evidence on how corporate governance mechanisms affect the extent of corporate voluntary disclosures. The sample consists of 27 firms listed on the consumer goods subsector of Indonesian Stock Exchange. The research covers the period of 2016 to 2018, resulting a total of 81 firm-year observations.

The result shows that board size and independence increase voluntary disclosure. This is in line with the agency theory that agency conflict and information asymmetry can be alleviated by voluntary disclosures, and it is the job of the commissioners to oversee the voluntary disclosures from the management. Bigger and more independent board can encourage management to disclose more information, not only to ease agency conflict and information asymmetry, but also to maximize firm value.

This research provides evidence that family ownership increases voluntary disclosure, which contrasts the previous findings. This can be explained by the cost-benefit analysis, that families with greater stake in the company bears more benefits from disclosure and more cost of non-disclosure. Disclosing certain news may lead to decrease in stock price and increase potential litigation issues, which consequently hurt the family net wealth. Hence, family firms choose to disclose information to avoid reputational and litigation costs. Meanwhile, institutional ownership does not significantly affect voluntary disclosure. This suggests that institutional investors pay more attention to financial information rather than voluntary disclosure. This research also finds that firm size and auditor size do not affect voluntary disclosure.

The limitations of this research include the use of content analysis method which conveys the subjectivity of the coders. Future research is expected to be conducted in other sectors or countries. 


\section{REFERENCES}

Akhtaruddin, M., \& Haron, H. (2010). Board Ownership , Audit Committees Effectiveness and Corporate Voluntary Disclosures. Asian Review of Accounting. 18(1), 68-82.

Allegrini, M., \& Greco, G. (2013). Corporate Boards, Audit Committees and Voluntary Disclosure: Evidence from Italian Listed Companies. Journal Management Governance, 17, 187-216.

Barako, D. G., Hancock, P., \& Izan, H. Y. (2006). Factors Influencing Corporate Disclosure by Kenyan Companies. Corporate Governance, 14(2), 107-125.

Cahyaningsih, \& Martina, V. Y. (2011). Pengaruh Mekanisme Corporate Governance And Karakteristik Perusahaan Terhadap Pengungkapan Tanggungjawab Sosial. Jurnal Siasat Bisnis, 15(2), 171-186.

Chau, G. \& Gray, S.J. (2010) Family Ownership, Board Independence and Voluntary Disclosure: Evidence from Hong Kong. Journal of International Accounting, Auditing and Taxation, 19, 93-109.

Chen, S., Chen, X., \& Ch, Q. (2008). Do family firms provide more or less voluntary disclosure? Journal of Accounting Research, 46(3), 499-536. https://doi.org/10.1111/j.1475-679X.2008.00288.x

Darmadi, S., \& Sodikin, A. (2013). Information Disclosure by Family-Controlled Firms The Role of Board Independence and Institutional Ownership. Asian Review of Accounting, 21(3), 223-240.

Dicko, S., Khemakhem, H., \& Zogning, F. (2019). Political connections and voluntary disclosure: the case of Canadian listed companies. Journal of Management and Governance. https://doi.org/10.1007/s10997-019-09471-3

Donnelly, R., \& Mulcahy, M. (2008). Board Structure , Ownership , and Voluntary Disclosure in Ireland. Corporate Governance, 16(5), 416-430. https://doi.org/10.1111/j.1467-8683.2008.00692.x

Effendi, M. A. (2009). The Power of Corporate Governance Teori and Implikasi. Jakarta: Salemba Empat.

Elfeky, M. I. (2017). The extent of voluntary disclosure and its determinants in emerging markets : Evidence from Egypt. The Journal of Finance and Data Science, 3(1-4), 45-59. https://doi.org/10.1016/j.jfds.2017.09.005

Eng, L. L., \& Mak, Y. T. (2003). Corporate governance and voluntary disclosure. Journal of Accounting and Public Policy, 22, 325-345. https://doi.org/10.1016/S02784254(03)00037-1

Fitri, A. (2016). Analisis Pengaruh Mekanisme Tata Kelola Perusahaan terhadap Luas Pengungkapan. AKRUAL: Jurnal Akuntansi, 7(2), 163-176.

Gantyowati, E., \& Nugraheni, R. L. (2014). The Impact of Financial Distress Status and Corporate Governance Structures on the Level of Voluntary Disclosure Within Annual Reports of Firms. Journal of Modern Accounting and Auditing, 10(4), 389403. 
Godfrey, J. ( 2010). Accounting Theory. Australia: John Wiley \& Sons.

Hadiprajitno, P. B. (2014). Struktur Kepemilikan, Mekanisme Tata Perusahaan and Biaya agensi di Indonesia. Jurnal Akuntansi and Auditing, 9(2), 97-127

Hamdani. (2016). Good Corporate Governance (Tinjauan Etika dalam Praktik Bisnis. Jakarta: Mitra Wacana Media.

Huafang, X., \& Jianguo, Y. (2007). Ownership structure, board composition and corporate voluntary disclosure Evidence from listed companies in China. Managerial Auditing Journal, 22(6), 604-619. https://doi.org/10.1108/02686900710759406. Jakarta: Salemba Empat.

Indriani, E. W. (2013). Faktor-faktor yang Mempengaruhi Luas Pengungkapan Sukarela and Implikasinya terhadap Asimetri Informasi. Accounting Analysis Journal, 2(2), 208-217.

Jensen, M., \& Meckling, W. (1976). Theory of The Firm: Managerial Behavior, Agency Costs, and Ownership Structure. Journal of Financial Economics, 3(4), 305-360.

KNKG Pedoman Umum Good Corporate Governance Indonesia. (2006).

Kolsi, M. C. (2017). The determinants of corporate voluntary disclosure policy: Evidence from the Abu Dhabi Securities Exchange (ADX). Journal of Accounting in Emerging Economies, 7(2), 249-265. https://doi.org/10.1108/JAEE-12-2015-0089

Makhija, A. K., \& Patton, J. M. (2004). The Impact of Firm Ownership Structure on Voluntary Disclosure : Empirical Evidence from Czech Annual Reports Published by: The University of Chicago Press The Impact of Firm Ownership Structure on Voluntary Disclosure: Empirical Evidence from Czech Ann. The Journal of Business, 77(3), 457-491.

Marfuah, \& Cahyono, Y. D. (2011). Karakteristik perusahaan and pengungkapan tanggung jawab sosial. Jurnal Akuntansi And Auditing Indonesia, 15(1), 103-119.

Poluan, G., \& Nugroho, P. I. (2015). Pengaruh Mekanisme Corporate Governance and Kondisi Financial Distress Terhadap Luas Pengungkapan Sukarela Dalam Laporan Tahun Perusahaan. Dinamika Akuntansi Keuangan And Perbankan, 4(1), 39-56.

Rafifah, U. R., \& Ratmono, D. (2015). Pengaruh Mekanisme Corporate Governance terhadap Pengungkapan Sukarela Laporan Tahunan. Journal of Accounting, 4, 1-13.

Samaha, K., \& Dahawy, K. (2011). An empirical analysis of corporate governance structures and voluntary corporate disclosure in volatile capital markets : The Egyptian experience An empirical analysis of corporate governance structures and voluntary corporate disclosure in volatile capit. International Journal of Accounting, Auditing and Performance Evaluation, 7(1), 61-93. https://doi.org/10.1504/IJAAPE.2011.037726

Sari, R.A. \& Juliarto, A., (2016). Interlock Dewan Direksi, Interlock Auditor Eksternal And Pengaruhnya Terhadap Pengungkapan Sukarela. Simposium Nasional Akuntansi XIX, Lampung, 2016. 
Silaban, Y. A. P. (2015). Pengaruh Corporate Governnace Terhadap Luas Pengungkapan Sukarela (Studi Empiris pada Perusahaan Perbankan yang Listing di BEI Tahun 2009-2012). Jom Fekon Universitas Riau. 2 (1), 1-15.

Skinner, D. (1994). Why Firms Voluntarily Disclose Bad News. Journal of Accounting Research, 32(1), 38-60. doi:10.2307/2491386

Soesetio, Y. (2008). Kepemilikan Manajerial and Institusional, Kebijakan Dividen, Ukuran Perusahaan, Struktur Aktiva, and Profitabilitas terhadap Kebijakan Hutang. Jurnal Keuangan and Perbankan, 12(3), 384-398

von Alberti-Alhtaybat, L., Hutaibat, K., \& Al-Htaybat, K. (2012). Mapping corporate disclosure theories. Journal of Financial Reporting and Accounting.

Wibowo, E. (2010). Implementasi Good Corporate Governance di Indonesia. Jurnal Ekonomi And Kewirausahaan, 10(2), 129-138. 